\title{
Europa vóór de Europese Gemeenschap van Kolen en Staal
}

Nederlandse civil society organisaties in het interbellum

Anne-Isabelle Richard

TVGESCH 130 (1): 21-45

DOI: 10.5117/TVGESCH2017.1.RICH

\begin{abstract}
Europe before the European Coal and Steel Community. Dutch civil society organisations in the interwar period

Before Robert Schuman proposed the creation of the European Coal and Steel Community in 1950, European cooperation had been long discussed, in particular by civil society actors. If we follow the New Political History approach and understand European integration as a process rather than as a set of events that started in the late ' 40 s, we need to analyse the interaction between state and civil society actors and examine this from a longer-term and global perspective.

The period after World War I saw intense debate on how to prevent war in Europe and about the changing position of Europe in the world. Ideas of European cooperation were central to these debates. This article will analyse the interaction between grass roots and elite activists in the interwar Dutch European movement. It will show how objectives and imaginations of a European future differed, included colonial arguments, and how this activity prepared the ground for initiatives after 1945.
\end{abstract}

Keywords: European integration, interwar period, civil society, Netherlands, colonialism

Geschiedenissen van de Europese integratie beginnen vaak na de Tweede Wereldoorlog. In de inleiding wordt meestal gerefereerd aan een aantal voordenkers, van Saint Simon tot Richard Coudenhove-Kalergi, waarna de aandacht verschuift naar de periode waarin 'de beslissingen' werden genomen en de formele instituties werden opgericht. ${ }^{1}$ Door sociale wetenschappers wordt deze periode vanaf 1950

1 Bijvoorbeeld Andrew Moravcsik, The choice for Europe. Social purpose and state power from Messina to Maastricht (Cornell 1998); Mathieu Segers, Reis naar het continent (Amsterdam 2013); Desmond Dinan, Europe recast. A history of European Union (Basingstoke 2014); de website van de Europese Unie: https://europa.eu/european-union/about-eu/history_en (geraadpleegd 19 september 2016). 
tot aan het Verdrag van Maastricht vaak aangeduid als de periode van de permissive consensus. ${ }^{2}$ Elites namen beslissingen die leidden tot Europese samenwerking en Europese samenlevingen gingen hier in mee zonder veel aandacht voor de gevolgen van deze beslissingen. De periode na Maastricht wordt gekarakteriseerd als constraining dissensus, waarin de beleidsvrijheid van de politiek beperkt wordt door kritiek van 'gewone burgers' op het Europese project. Dit artikel pleit voor een nuancering van deze tegenstelling door het proces van Europese integratie in breder perspectief te plaatsen en ook de periode vóór 1950 en civil society organisaties te onderzoeken. Deze methode maakt langere continuïteiten van terughoudende Nederlandse steun voor Europese integratie zichtbaar.

Als we willen begrijpen hoe de beslissingen over Europese integratie tot stand kwamen, hoe de geesten rijp gemaakt werden om deze beslissingen te (laten) nemen, hoe het proces van de Europese integratie tot stand kwam, kan de New Political History-aanpak uitkomst bieden. De speerpunten van de New Political History die voor dit artikel met name relevant zijn, zijn het benaderen van de geschiedenis van de Europese samenwerking als proces, de aandacht voor niet-statelijke actoren en de nuancering van het onderscheid tussen binnen- en buitenlandse politiek. ${ }^{3}$ Dit betekent in dit geval dat we verder terug gaan in de tijd, civil society actoren in de analyse betrekken en de interactie tussen het nationale, koloniale,

2 Liesbeth Hooghe en Gary Marks, 'A postfunctionalist theory of European integration: From permissive consensus to constraining dissensus', British Journal of Political Science 39.1 (2009) 1-23.

3 Zie ook de inleiding van Wim van Meurs.
Europese en mondiale niveau onderzoeken. Door de aandacht te richten op het interbellum kunnen zowel voorlopers, alternatieven, als de redenen waarom beslissingen voor Europese samenwerking vanaf $195^{\circ}$ werden genomen zoals ze genomen werden beter begrepen worden.

Deze bijdrage richt zich op de Nederlandse Europese beweging in de periode tussen de twee wereldoorlogen. Tot voor kort gingen historici er van uit dat er in Nederland geen Europese beweging bestond in het interbellum. ${ }^{4}$ Hoewel de Nederlandse Europese beweging minder groot was dan de Franse, Belgische of Duitse, waren er in Nederland in het interbellum verschillende organisaties die lobbyden voor Europese samenwerking. ${ }^{5}$ De leden van deze organisaties waren zowel 'prominenten', invloedrijke personen uit het bedrijfsleven, de wetenschap, de journalistiek en de politiek, als meer alle-

4 H.A.M. Klemann, 'Gedanken zur europäischen Integration in den Niederlanden während des Interbellums', in: J. Bosmans ed., Europagedanke, Europabewegung und Europapolitik in den Niederlanden und Deutschland seit dem ersten Weltkrieg (Münster 1996) 79-99; H.A.M. Klemann, 'The Dutch reaction to the Briand Plan', in: A. Fleury en L. Jilek ed., Le plan Briand d'Union Fédérale Européenne. Perspectives nationales et transnationales, avec documents (Bern 1998) 147169; A. van Heerikhuizen, Pioniers van een Verenigd Europa: Bovennationaal denken in het Nederlandse parlement 1946-1951 (Diss. Universiteit van Amsterdam 1998) 39.

5 J-L. Chabot, Aux origines intellectuelles de l'Union européenne. L'idée d'Europe unie de 1919 à 1939 (Grenoble 2005); G. Duchenne, Esquisses d'une Europe nouvelle. L'Europeisme dans la Belgique de l'entre-deuxguerres (1919-1939) (Brussel 2008); Verena Schöberl, 'Es gibt ein großes und herrliches Land, das sich selbst nicht kennt... es heißt Europa.' Die Diskussion um die Paneuropaidee in Deutschland, Frankreich und Großbritannien 1922-1933 (Berlijn 2008). 
daagse activisten, 'idealistische winkeliers', zoals het Franse Gezantschap in Nederland hen beschreef. ${ }^{6}$ Door deze twee groepen in samenhang te onderzoeken wordt de variëteit aan Europese plannen getoond, kan geanalyseerd worden wie, wat, waarom ondersteunde en kan de tegenwoordig veelgehoorde tweedeling tussen 'elite' en 'gewone burgers' enigszins genuanceerd worden.

Deze Europese organisaties vormden onderdeel van het Nederlandse maatschappelijke middenveld. Door dergelijke civil society organisaties te onderzoeken heeft dit artikel een andere focus dan de traditionele Europese integratie geschiedenis die zich richt op statelijke actoren. De meeste Europese civil society organisaties opereerden op verschillende niveaus, van lokaal tot nationaal en Europees. Door deze verschillende niveaus in de analyse te betrekken worden traditionele analyses van het nationale of Europese niveau automatisch uitgebreid met een analyse van de interactie tussen de niveaus. Door de geschiedenis als proces te benaderen, prominente en alledaagse niet-statelijke actoren in samenhang te onderzoeken en de interactie tussen de verschillende niveaus te onderzoeken sluit dit artikel aan bij recente ontwikkelingen in de transnationale geschiedenis en New Political History.

Tenslotte laat dit artikel het belang van een bredere benadering van Europese integratie-geschiedenis zien door ook de invloed van ontwikkelingen buiten Europa mee te nemen. De Nederlandse casus laat

6 Ministère des Affaires Etrangères (MAE), Serie Y Internationale, 657, Légation française aux Pays Bas, dépêche no. 149, 20 maart 1933.

7 Wolfram Kaiser e.a. ed., Transnational networks in regional integration: governing Europe 1945-83 (Basingstoke 2010). goed zien hoe, juist in het interbellum, ontwikkelingen buiten Europa zoals opkomende nationalistische bewegingen samen met koloniale overwegingen de steun voor en het proces van Europese samenwerking beïnvloedden. Zo speelt dit artikel in op recente historiografische ontwikkelingen die het belang van de wereld buiten Europa en dan vooral de koloniale wereld voor Europese integratie benadrukken. ${ }^{8}$ Het verband tussen Europese samenwerking tijdens het interbellum en tijdens de dekolonisatieperiode na de Tweede Wereldoorlog wordt zo ook duidelijk.

Dit artikel schetst de Europese beweging in Nederland door in te gaan op twee organisaties: de belangrijkste alledaagse, grassroots-organisatie, de Vereeniging voor de Vereenigde Staten van Europa (VSE) en de internationaal meest bekende organisatie die in Nederland een gemengde achterban van prominenten en gewone burgers had, Paneuropa Nederland. Tezamen geeft een analyse van deze twee organisaties een goed beeld van het Europese sentiment in Nederland tijdens het interbellum en komen de verschillen van inzicht tussen de elite en grassroots-organisaties naar voren. Dit artikel laat zien dat Nederland een Europese

8 M.T. Bitsch en G. Bossuat, ed., L'Europe Unie et L'Afrique: de L'idee d'Eurafrique à la Convention de Lomé 1 (Brussel 2005); Anne-Isabelle Richard, Colonialism and the European movement in France and the Netherlands, 1925-1936 (Diss. Cambridge 2010); Martin Rempe, 'Decolonization by Europeanization? The early EEC and the transformation of French-African relations', KFG Working Papers Series, no. 27, mei 2011, Kolleg-Forschergruppe (KFG) 'The Transformative Power of Europe', Freie Universität Berlin; Veronique Dimier, The invention of a European development aid bureaucracy (Basingstoke 2014); Peo Hansen en Stefan Jonsson, Eurafrica. The untold history of European integration and colonialism (Londen 2014). 
beweging kende, maar dat de wereldwijde belangen van een neutrale koloniale vrijhandelsnatie als rem fungeerden, vooral voor de elite. Toen deze belangen anders kwamen te liggen, eerst tijdens de Grote Depressie, vervolgens na de Tweede Wereldoorlog, werd het draagvlak voor bepaalde aspecten van Europese samenwerking vergroot. Als we het proces van steeds nauwere Europese samenwerking na 1945 beter willen begrijpen en ook de rol van Nederland daarin plaatsen zijn de overeenkomsten en verschillen met de ervaringen tijdens de Eerste Wereldoorlog en het interbellum noodzakelijk om de rol van de bezetting en de dekolonisatie van Indonesië nog sterker te linken aan een Europese ommezwaai. Daarnaast plaatst deze bijdrage de Nederlandse terughoudendheid tijdens de onderhandelingen over de Europese Gemeenschap van Kolen en Staal ook in een langere traditie waarbij de mondiale belangen van Nederland nooit uit het oog verloren werden en worden. ${ }^{9}$ Hierdoor wordt duidelijk dat Europese oplossingen voor Nederland vaak een tweede keus waren, hetgeen het contrast tussen het zogenaamde Europese enthousiasme van de 'elite' in de periode van permissive consensus en het huidige kritisch volgen van de Europese Unie door de 'gewone burger' relativeert.

\section{Europa in het interbellum}

Buiten Nederland bestaat er een aanzienlijke literatuur over Europese samenwerking in het interbellum. Deze literatuur heeft, als een New Political History avant

9 Cf. ook A.G. Harryvan, In pursuit of influence. The Netherlands' European Policy during the formative years of the European Union, 1952-1973 (Brussel 2009). la lettre, zowel statelijke initiatieven als niet-statelijke actoren onderzocht. Daarnaast zijn zowel interstatelijke verhoudingen als nationale contexten en transnationale contacten geanalyseerd, op politiek, economisch en cultureel gebied. ${ }^{10}$ Deze literatuur heeft verklaard waarom de Franse minister van Buitenlandse Zaken, Aristide Briand, in 1929 in de Volkenbond een voorstel deed om een 'soort van federale link tussen de Europese volkeren te creëren'. "l Hierbij versterkten buitenlandse politieke omstandigheden en de binnenlandse situatie elkaar. Briand had in 1926 weliswaar 'Europees gesproken' met zijn Duitse collega Gustav Stresemann om de spanningen tussen de twee landen te verminderen, maar de spanningen in Europa waren hierdoor niet verdwenen. In Frankrijk was Briand weliswaar zeer populair, maar er waren tekenen dat de politieke machtsverhouding in zijn nadeel zou omslaan. Dit maakte dat het moment opportuun leek voor een nieuw initiatief om de cycli van Europese en Franse spanning te doorbreken: Europese samenwerking. De redenen waarom het plan vervolgens werd gestald in de Onderzoekscommissie voor Europese Samenwerking van de Volkenbond zijn ook geanalyseerd. ${ }^{12}$ Vlak na Briands speech in Genève vond de Wall Street Crash plaats. Hoewel de speech economische samenwerking suggereerde, stelde het Franse memorandum van mei 1930 waarin het plan werd uitgewerkt politieke samenwer-

10 G. Bossuat ed., Inventer l'Europe. Histoire des groupes d'influence et des acteurs de l'idée européenne (Brussel 2003).

11 J. Barièty, Aristide Briand la Société des Nations et l'Europe 1919-1932 (Straatsburg 2007).

12 Ibidem; Fleury en Jilek, Le Plan Briand; S. Schirmann, ed., Organisations internationales et architectures européennes 1929-1939 (Metz 2003). 
king voorop. ${ }^{13}$ Dit vonden veel staten te ver gaan, al helemaal omdat Briand goedgezinde politici waarmee hij het Verdrag van Locarno had gesloten, Stresemann en de Britse minister van Buitenlandse Zaken Austen Chamberlain, niet langer in functie waren. ${ }^{14}$

Naast dit statelijk perspectief heeft deze literatuur ook laten zien dat Briands (voorzichtige) idee van Europese samenwerking niet uit het niets kwam, maar dat er een brede beweging in heel Europa actief was die riep om samenwerking. Deze beweging bestond uit een aanzienlijk aantal nationale en transnationale organisaties die hier verschillende ideeën bij hadden. Vooral in Frankrijk, Duitsland en midden Europa waren organisaties actief. Deze telden zowel zeer prominente als meer alledaagse leden. Sommige lokale verenigingen hadden enkele tientallen, andere, zoals Paneuropa, tienduizenden leden over heel Europa. ${ }^{15}$ De grootste bloeiperiode verschilde per land, zoals ook de 'late' Nederlandse casus laat zien, maar in het algemeen waren de jaren 1924-1931 het belangrijkst. ${ }^{16}$ Hoewel deze organisaties in de praktijk vaak overlappende beweegredenen hadden, kan er een onderscheid gemaakt worden tussen

13 MAE, Papiers 1940, Leger, 3, Mémorandum sur l'organisation d'un régime d'union fédérale européenne, 1 mei 1930.

14 Stresemann overlijdt een maand na Briands speech in oktober 1929, de regering waar Chamberlain deel van uitmaakte verliest de verkiezingen in de zomer van 1929. R.W.D. Boyce, 'Britain's first 'No' to Europe: Britain and the Briand Plan, 1929-1930', European Studies Review 10.1 (1980) 17-45.

15 A. Ziegerhofer-Prettenthaler, Botschafter Europas. Richard Nikolaus Coudenhove-Kalergi und die Paneuropa-Bewegung in den zwanziger und dreißiger Jahren (Wenen 2004).

16 Chabot, Aux origines intellectuelles de l'Union Européenne. drie hoofdmotieven om Europese samenwerking na te streven: politiek-pacifistische, economische en culturele redenen.

$\mathrm{Na}$ de gruwelen van de Eerste Wereldoorlog speelden politiek-pacifistische redenen in bijna alle Europese organisaties een rol. De oorlog was zo vreselijk geweest dat de Europese staten alles zouden moeten doen om een nieuwe oorlog te voorkomen. Dit sentiment was het sterkst binnen Franse bonden van oud-strijders. Hun doel om oorlog koste wat kost te voorkomen zou sommigen van hen in de jaren veertig tot collaboratie brengen. ${ }^{17}$ Minder vergaande vormen van pacifisme zorgden binnen de vredesbeweging voor interesse voor Europese samenwerking. De relatie met de Volkenbond speelde hierbij een grote rol. Deze wereldwijde organisatie was na de Eerste Wereldoorlog opgericht om nieuwe oorlogen te voorkomen. Voor sommige, zoals de Franse Volkenbondvereniging, was Europese samenwerking een aanvulling op het werk van de Volkenbond zelf. Voor anderen, zoals de Britse Volkenbondvereniging, betekende Europese samenwerking concurrentie voor de Volkenbond die hierdoor haar mondiale werk niet meer zou kunnen doen. ${ }^{18}$ De Nederlandse Vereniging voor Volkenbond

17 B. Bruneteau, 'L'Europe nouvelle' de Hitler: une illusion des intellectuels de la France de Vichy (Monaco 2003); N. Ingram, The politics of dissent. Pacifism in France 1919-1939 (Oxford 1991).

18 Anne-Isabelle Richard 'Competition and complementarity: civil society networks and the question of decentralising the League of Nations', Journal of Global History 7.2 (2012) 233-256. Het Franse standpunt werd vertegenwoordigd door de Fédération Française des Associations pour la Société des Nations, het Britse door League of Nations Union. 


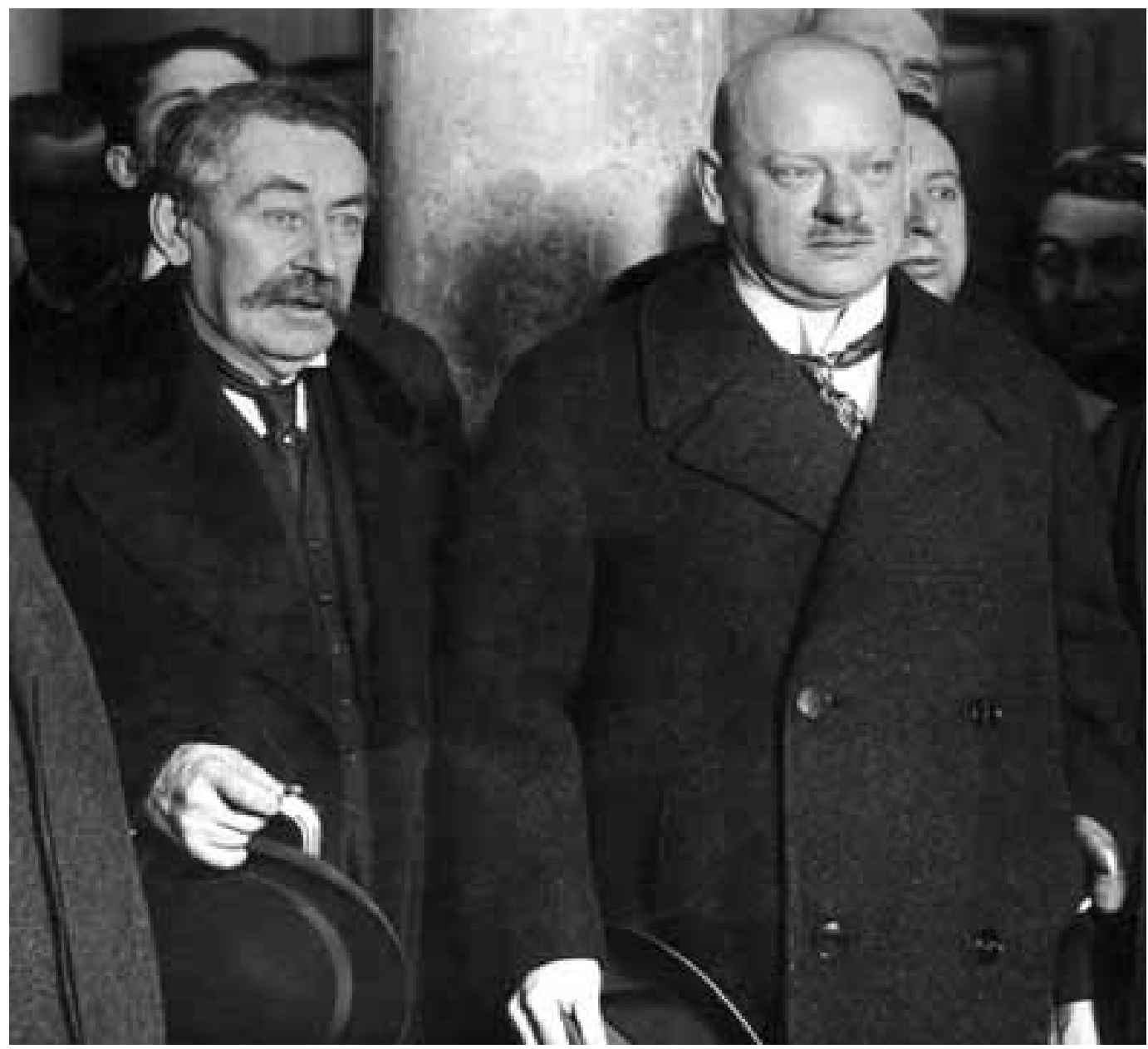

Aristide Briand (links, 1862-1932) en Gustav Stresemann (1878-1929) in 1926, het jaar waarin zij samen de Nobelprijs voor de Vrede toegekend kregen

Fotograaf onbekend, Wikimedia Commons

en Vrede neigde ook naar deze laatste positie. $^{19}$

De enorme groei aan handelsbelemmeringen (met name douanetarieven) tussen de Europese staten na de Eerste Wereldoorlog leidde tot interesse voor Europese samenwerking binnen de industrie, het bedrijfsleven en onder economen. Ook hier was sprake van uiteenlopende ideeën, van

19 Anne-Isabelle Richard, 'The curious case of Dutch Europeanism', in: Ruud van Dijk e.a. ed., Shaping foreign relations: The Netherlands 1815-200o (New York te verschijnen 2017). het verlagen van douanetarieven, tot de vorming van douane-unies en kartels. ${ }^{20}$ Een organisatie die deze benaderingen

20 E. Bussière, La France, la Belgique, et l'organisation économique de l'Europe, 1918-1930 (Parijs 1992); Laurence Badel, Un milieu libéral et européen. Le grande commerce français 1925-1948 (Parijs 1999). 
combineerde was de Union Douanière Européenne (UDE). De UDE was vooral actief in Frankrijk, Duitsland en Hongarije, maar ook in Nederland werd een comité opgericht, de Entente Douanière Européenne. ${ }^{21}$ In eerste instantie richtte de UDE zich op het verlagen van douanetarieven waarna een Europese douane-unie opgericht kon worden. Deze ideeën sloten aan bij pogingen van de Volkenbond om een 'wapenstilstand' op douanegebied te bewerkstelligen rond $1930 .{ }^{22}$ Een tweede doel werd de oprichting van kartels en industriële ententes. Kartels speelden een belangrijke rol binnen het bedrijfsleven. Industriëlen, van de Luxemburgse staalproducent Emile Mayrisch (zijn ARBED was lid van het Internationaal Staalkartel) tot de Nederlandse gloeilampenfabrikant Anton Philips (Phoebus kartel), deden zo pogingen om de handelsbelemmeringen aan de landsgrenzen te beperken en de Europese economie gaande te brengen en houden. ${ }^{23}$

21 L'Europe de Demain, 1.1 (1927). Anne-Isabelle Richard, 'Les Pays-Bas entre Europe et le monde: l'européisme hésitant aux Pays-Bas pendant l'entre-deuxguerres', in: Landry Charrier en Nicholas Beaupré ed., Unir et construire l'Europe: circulations, transferts et croisements des projets européens du XVIIIe siècle au milieu du XXe siècle, Siècles. Cahiers du CHEC $41 / 1$ (2015).

22 In 1930 organiseerde de Volkenbond een conferentie om een Douane Wapenstilstand te bewerkstelligen. Patricia Clavin, Securing the world economy. The reinvention of the League of Nations, 1920-1946 (Oxford 2013).

23 Charles Barthel, 'Emile Mayrisch et le pacte international de l'acier des années 1920', Journal of European Integration history 1 (2006) 43-65; J. Bariéty, 'Le rôle d'Emile Mayrisch entre les sidérurgies allemande et française après la première guerre mondiale', Relations Internationales no. 1 mei (1974) 123-134, E. Hexner, The International Steel Cartel (Londen 1946); I.J. Blanken, Geschiedenis van de Koninklijke Philips $N V$, deel 5. Een industriële wereldfederatie (Zaltbommel 2002); M. Metze, Ze zullen weten wie ze voor zich hebben. Anton Philips, 1874-1951 (Amsterdam 2004).
Daarnaast waren ze ook actief in meer algemene of culturele Europese initiatieven. Mayrisch en zijn vrouw Renée Mayrisch organiseerden bijvoorbeeld de Cercle de Colpach waar zij intellectuelen uit Frankrijk en Duitsland ontvingen en zo FransDuitse verzoening probeerden te stimuleren. Mayrisch en Philips waren daarnaast ook lid van de Paneuropa Union, de bekendste algemene Europese vereniging in het interbellum.

Richard Coudenhove-Kalergi, de oprichter van Paneuropa, wordt in bijna alle literatuur over Europese integratie na 1945 genoemd als dé voordenker van Europese samenwerking, samen met Briand. Zijn ideeën en de invloed die zij hadden worden in deze post-1945 literatuur echter nauwelijks geanalyseerd. Toch bestaat er een uitgebreide historiografie over Coudenhove en Paneuropa. Deze analyseert de activiteiten van deze Oostenrijks-Hongaarse graaf met Japanse moeder vanaf de publicatie van zijn boek, Paneuropa, in 1923 en de oprichting van de Paneuropa Union een jaar later tot zijn ballingschap in New York en zijn activiteiten na de Tweede Wereldoorlog. ${ }^{24} \mathrm{Zijn}$ eclectische ideeën, verwerping van het communisme en nationaalsocialisme, organisatorische en propagandistische successen en moeizame verhouding tot de Europese ministeries van Buitenlandse Zaken komen hierbij aan bod. Zijn be-

24 Ziegerhofer-Prettenthaler, Botschafter Europas; K. Orluc, 'A last stronghold against fascism and National Socialism? The Pan-European debate over the creation of a European party in 1932', Journal of European Integration History 8.2 (2002) 23-44; M. Gehler, 'Richard Coudenhove-Kalergi, Panueropa und Osterreich 1923-1972', in: Demokratie und Geschichte. Jahrbuch des Karl von Vogelsang-instituts zur Erforschung der Geschichte der Christlichen Demokratie in Osterreich 2 (1998) 143-194; Schöberl, 'Es gibt ein großes und herrliches Land'. 


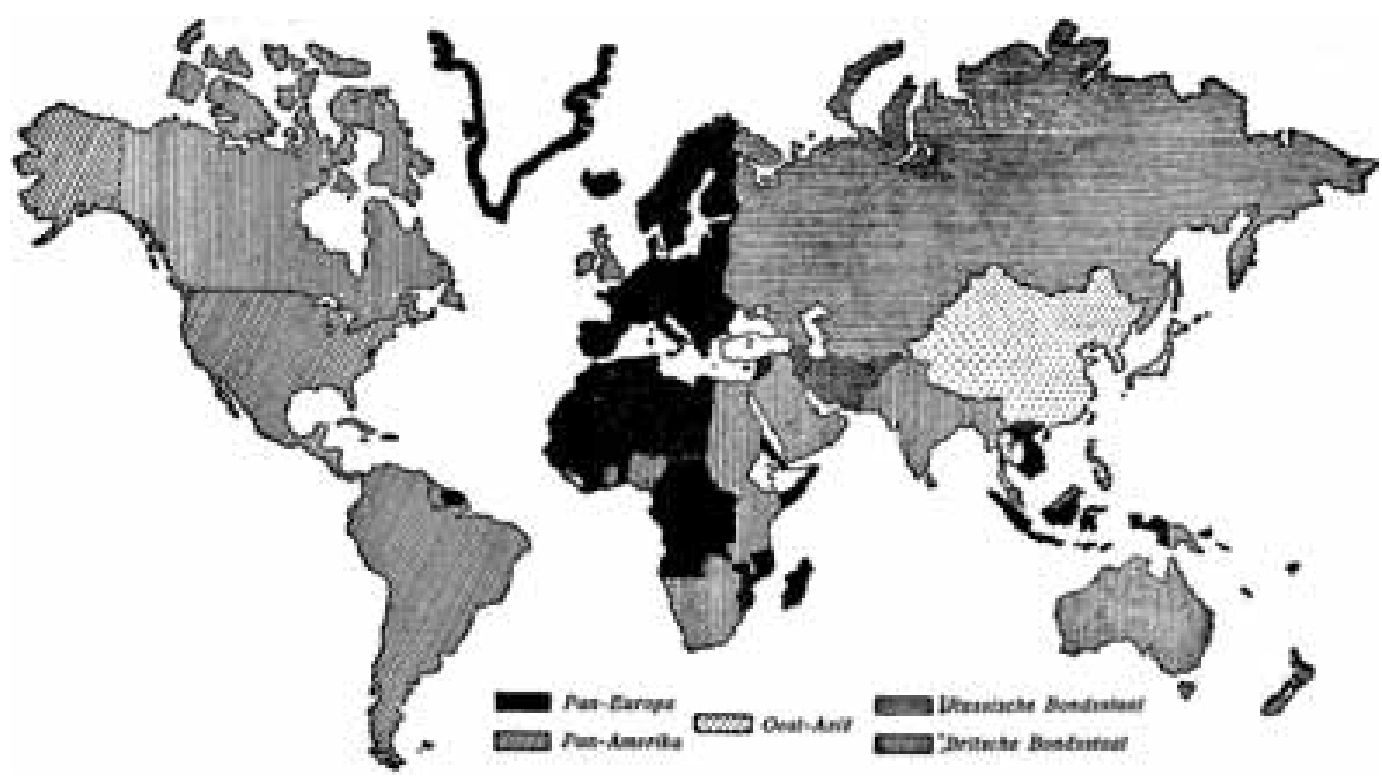

Wereldkaart met 5 krachtenvelden in de wereld: Pan-Europa, Pan-Amerika, Oost-Azië, Russische Bondstaat en de Britsche Bondstaat

R. Coudenhove-Kalergi, Paneuropa, 1923/1928

weegredenen voor Europese samenwerking lagen enerzijds in de ervaring van de Eerste Wereldoorlog in Europa zelf, anderzijds in de effecten van de oorlog buiten Europa. Dit leidde tot een wereldwijde geopolitieke analyse die in de literatuur minder aandacht gekregen, maar zeer wijdverspreid was in het Europa van het interbellum. Deze analyse benadrukte het belang van de wereld buiten Europa voor Europese samenwerking. Coudenhove was, zoals veel Europeanen, overtuigd van de superioriteit van de Europese cultuur en de rol die Europeanen in de wereld te spelen hadden. Hij was zich echter ook bewust van de groeiende macht en invloed van niet-Europeanen, zoals de Verenigde Staten, Japan of de Sovjet-Unie (die hij dus buiten Europa plaatste). Deze opkomende machten droegen daarnaast bij aan de vorming van machtsblokken in de wereld. Coudenhove onderscheidde 'Panamerika', 'Oost-Azië', de Sovjet-Unie en het Britse Rijk. Als Europa haar positie in de wereld wilde behouden moest ten eerste een nieuwe Europese oorlog voorkomen worden en moesten ten tweede de Europese staten gaan samenwerken. ${ }^{25}$

De Paneuropa Union was de grootste Europese organisatie in het interbellum en werd gesteund door politici - van links en rechts -, industriëlen, intellectuelen en tot op zekere hoogte 'de gewone man', hoewel Coudenhove daar zelf minder geinteresseerd in was. ${ }^{26}$ Paneuropa is echter

25 J-L. Chabot, 'Le primat de la civilisation occidentale au principe des premiers plans d'Europe unie', in: B. Bruneteau en Y. Cassis ed., L'Europe communautaire au défi de la hiérarchie (Brussel 2007) 37-56; Richard, Colonialism and the European movement; Anne-Isabelle Richard, 'In search of a suitable Europe: Paneuropa and the Netherlands in the interwar period', in: C. Reijnen en M. Rensen ed., European encounters: Intellectual exchange and the rethinking of Europe 1914-1945, European Studies: an interdisciplinary series in European culture, history and politics (Amsterdam 2014) 247-269. 26 Orluc, 'A last stronghold'. 
niet de enige organisatie die de drie terreinen, van cultureel, politiek en economisch europeanisme, bestreek. Een ander voorbeeld is het Comité Français de Coopération Européenne waartoe Duitse en Franse parlementariërs in 1925 de eerste aanzet gaven. ${ }^{27}$ Deze organisatie werd vooral actief in Frankrijk, streefde regionale Europese samenwerking binnen het kader van de Volkenbond na en had daarom goede contacten met Europese Volkenbondsverenigingen.

Deze Europawijde literatuur laat zien dat in het interbellum Europese samenwerking vanuit verschillende hoeken van de Europese samenlevingen werd bediscussieerd en nuanceert hiermee de traditionele chronologie die Europese samenwerking rond de Tweede Wereldoorlog laat ontstaan. De Eerste Wereldoorlog had een beslissende invloed op het denken over Europese samenwerking. De gevolgen van de oorlog binnen Europa en de opkomst van andere machtscentra buiten Europa leidden tot het gevoel dat de Europese volkeren en staten moesten samenwerken. Tijdens het interbellum werden veel mogelijke oplossingen voor de Europese problemen onderzocht. Tot het gehoopte resultaat leidden zij niet, maar dat maakt deze oplossingen voor de historicus niet minder relevant. $\mathrm{Na}$ de Tweede Wereldoorlog bouwden politici en activisten voort op deze plannen, discussies en netwerken. Hiermee wordt geen lineair begrip van de geschiedenis voorgesteld. Juist de verschillende mogelijkheden, het proces, gevoed door state-

27 J.-M. Guieu, 'Le Comité fédéral de Coopération européenne: L'action méconnue d'une organisation internationale privée en faveur de l'union de l'Europe dans les années trente (1928-1940)', in: S. Schirmann ed., Organisations internationales et architectures européennes (1929-1939) (Straatsburg 2003) 73-91. lijke en niet-statelijke actoren, worden hiermee aangegeven, die afhankelijk van de context wel of niet tot resultaat leidden.

\section{Nederland tijdens het interbellum}

Hoewel Europawijde tendensen duidelijk herkenbaar zijn, blijven nationale contexten zeer invloedrijk - dat blijkt ook uit de Nederlandse casus. Hoewel internationalisme een belangrijk onderdeel van de $\mathrm{Ne}$ derlandse identiteit was en de vredesbeweging vrij sterk was, stond Europese samenwerking niet meteen hoog op de agenda van beleids- en opiniemakers. ${ }^{28}$ Daarnaast waren de drie hoofdredenen voor Europese samenwerking in het interbellum in Nederland niet allemaal even sterk vertegenwoordigd. (Vrijblijvende) culturele en intellectuele ideeën gericht op een Europese Republiek der Letteren werden ook in Nederland ondersteund, door intellectuelen zoals Johan Huizinga. ${ }^{29}$ Economische projecten werden vanaf het begin van de jaren dertig in toe-

28 Remco van Diepen, Voor Volkenbond en Vrede. Nederland en het streven naar een nieuwe wereldorde 1919-1946 (Amsterdam 1999); P. Malcontent en F. Baudet, 'The Dutchman's burden? Nederland en de internationale rechtsorde in de twintigste eeuw', in: B. de Graaff e.a. ed., De Nederlandse buitenlandse politiek in de twintigste eeuw (Amsterdam 2003) 69-104; Michael Riemens, De passie voor vrede de evolutie van de internationale politieke cultuur in de jaren 1880-1940 en het recipiëren door Nederland (Groningen 2005); Duco Hellema, Dutch Foreign policy. The role of the Netherlands in world politics (Dordrecht 2009).

29 Anne-Isabelle Richard, 'Huizinga, intellectual cooperation and the spirit of Europe, 1933-1945', in: Mark Hewitson en Matthew D'Auria ed., Europe in crisis. Intellectuals and the European idea, 1917-1957 (Oxford 2012) 243-256; Annemarie van Heerikhuizen, 'Paris 1933: A 'Société des Esprits' chaired by Paul Valéry', in: Reijnen en Rensen, European encounters, 139-154. 
nemende mate onderzocht, maar politiekpacifistische redenen voor Europese samenwerking waren in het neutrale Nederland veel minder invloedrijk dan elders in Europa. In Nederland was het geloof in wereldwijde initiatieven van de Volkenbond veel belangrijker; voorstellen die het werk van de Volkenbond konden schaden, zoals Europese samenwerking, werden gewantrouwd. Dit wantrouwen had zowel betrekking op vrede en veiligheid als op economische belangen. De drie uitgangspunten die oud-minister Joris Voorhoeve in 1979 samenvatte als peace, profits and principles zijn zeer van toepassing op het Nederlandse buitenlandse beleid in het interbellum. ${ }^{30} \mathrm{Als}$ kleine neutrale handelsnatie met grote overzeese gebiedsdelen was Nederland afhankelijk van een wereldwijd systeem van internationaal recht dat neutraliteit respecteerde. In een uiterst geval was het afhankelijk van Engelse steun. ${ }^{31}$ Europese samenwerking zou leiden tot blokvorming, tegengesteld aan Nederlandse wereldwijde belangen, en tot internationale spanningen tussen de blokken die de wereldvrede niet ten goede zou komen. Daarnaast spiegelde Nederland zich aan, en steunde zoals vermeld op, Groot-Brittannië dat weliswaar zwaar getekend was door de Eerste Wereldoorlog, maar waar het Empire, vrijhandel en wereldwijde vre-

30 J.J.C. Voorhoeve, Peace, profits and principles. A study of Dutch foreign policy (Den Haag 1979). Zie ook Malcontent en Baudet, 'The Dutchman's burden?'.

31 Van Diepen, Voor Volkenbond en Vrede. desinitiatieven zoals de Volkenbond als de weg naar de toekomst gezien werden. ${ }^{32}$

Gezien de hierboven beschreven situatie, leek er in Nederland weinig belangstelling voor Europese samenwerking te bestaan. ${ }^{33}$ Deze indruk is vooral het gevolg van de nadruk die de Nederlandse literatuur tot voor kort legde op statelijke factoren en dan met name op het sceptische ministerie van Buitenlandse Zaken. Als andere dan de klassiek politieke of diplomatieke actoren in de analyse betrokken worden, wordt duidelijk dat er ook in Nederland interesse in Europese samenwerking bestond.

Daar waar voor alledaagse activisten idealistisch-pacifistische en federalistische ideeën een grote rol speelden, gaven voor prominenten veranderende omstandigheden de doorslag. De depressie van de jaren dertig had grote gevolgen voor de Nederlandse economie. Met name de impact op de landbouw, die tijdens de Eerste Wereldoorlog zo belangrijk was gebleken, leidde tot een omslag in het denken over vrijhandel en de Gouden Standaard.$^{34}$ Het politiek en economisch multilateralisme van de Volkenbond leek geen oplossing te kunnen bieden voor geopolitieke span-

32 R.T. Griffiths, 'Free Traders' in a protectionist world: the foreign policy of the Netherlands 1930$195^{\circ}$ (with particular reference to Europe)' in: S. Groenveld en M. Wintle ed., Britain and the Netherlands: State and trade, government and the economy in Britain and the Netherlands since the Middle Ages (Zutphen 1988) 152-168; N. Ashton en D. Hellema ed., Unspoken allies: Anglo-Dutch relations since 1780 (Amsterdam 2001).

33 Klemann, 'Gedanken zur europäischen Integration'; Idem., 'The Dutch reaction to the Briand Plan'. 34 R.W.J.M. Bos, 'De depressie der jaren dertig: Aspecten van Nederland als een kleine open volkshuishouding in het bijzonder met betrekking tot de uitvoer van levensmiddelen naar Engeland', in: P.W. Klein en G.J. Borger ed., De jaren dertig: Aspecten van crisis en werkloosheid (Amsterdam 1979) 22-37. 
ningen en de problemen van de economische depressie. Ook raakten beleids- en opiniemakers en industriëlen gedesillusioneerd in Groot-Brittannië. Een aantal Britse beleidswijzigingen had voor Nederland grote economische gevolgen. GrootBrittannië verliet de voor Nederland zo belangrijke Gouden Standaard, beperkte haar eigen vrijhandelspolitiek ten faveure van imperial preference, terwijl het kleinere initiatieven om de handel weer op gang te krijgen, zoals het Verdrag van $\mathrm{Ou}$ chy uit $193^{2}$ tussen Nederland, België en Luxemburg bemoeilijkte met een beroep op de Meestbegunstigingsclausule. Dit alles leidde ertoe dat ook in Nederland alternatieven voor de traditionele politiek van de Gouden Standaard en vrijhandel onderzocht werden. De (positieve) ervaringen van industriëlen zoals Anton Philips met kartels zorgden voor een verdere stimulans in deze zoektocht naar economische alternatieven.

Zoals vermeld kwam het Europese sentiment in Nederland later op dan elders in Europa. ${ }^{35}$ Als we de blik verleggen van het sceptische Nederlandse ministerie van Buitenlandse Zaken naar niet-statelijke actoren, wordt duidelijk dat begin jaren dertig ideeën van Europese samenwerking wel degelijk opgang maakten. De in principe aarzelende houding in combinatie met de ontwikkeling van de economische depressie verklaren waarom het $\mathrm{Eu}-$ ropese sentiment in Nederland later opkwam dan elders in Europa. In Nederland waren de jaren 1929-1933 het belangrijkst. Hierin zien we ook een verschil tussen een pragmatische, economisch geïnspireerde

35 Jean-Luc Chabot ziet bijvoorbeeld de jaren 19241931 als de bloeiperiode van Europese organisaties in Frankrijk. Chabot, Aux origines intellectuelles de l'Union Européenne. elite en organisaties van meer alledaagse activisten, die al eerder werden opgericht, nauw verwant waren met de (meer radicale) vredesbeweging en Europees federalisme niet afwezen. Deze verschillen en overeenkomsten zullen hieronder nader beschouwd worden aan de hand van een casus van een meer alledaagse grassrootsvereniging, en een Europese organisatie die ook prominenten onder haar leden telde in het Nederland van het interbellum.

\section{'Idealistische winkeliers' ${ }^{36}$}

De Vereeniging ter bevordering van de Oprichting der Vereenigde Staten van Europa (VSE), opgericht in 1925, was een van de eerste Europese verenigingen in Nederland. ${ }^{37}$ De ongeveer zeventig leden bij oprichting kwamen uit de (gegoede) burgerij. ${ }^{38}$ Het ledenaantal groeide in de loop der tijd. De president van de VSE was Hendrik Müller, een gepensioneerde leraar klassieke talen en auteur van de brochure 'International European law: an essay on the future United States of Europe'. ${ }^{39}$ De organisatie publiceerde een aantal brochures die werden vertaald in het Engels, Frans, Duits en Esperanto. Het was een organisatie die voortkwam uit de vredesbeweging en lid was van de Nooit-

36 MAE, Serie Y Internationale, 657, Légation française aux Pays Bas, dépêche no. 149, 20 maart 1933. 37 De eerste Nederlandse Europese beweging was de Europeesche Statenbond, opgericht in 1914 door Nico van Suchtelen, zie: N. van Suchtelen, Het eenige redmiddel. Een Europeesche Statenbond (Amsterdam 1914).

38 Internationaal Instituut voor Sociale Geschiedenis, Amsterdam (IISG), Müller, 16.63, Ledenlijst 17 april 1926.

39 H.C. Müller, International European Law an essay on the future United States of Europe (Den Haag 1924). 
Meer-Oorlog-Federatie, de overkoepelende federatie van (meer radicale) vredesbewegingen in Nederland. ${ }^{40}$

In 1926 publiceerde de VSE een 'Korte uiteenzetting' met de uitgangspunten van de vereniging. ${ }^{41}$ De VSE zag de Verenigde Staten van Europa als een middel om te werken voor een hogere Europese beschaving en cultuur en voor het uitbreiden van de invloed van Europa in de wereld. De vereniging werd geïnspireerd door ideeën over Europese achteruitgang. De VSE vond dat Europa nog steeds bovenaan de beschavingsladder stond, maar om die positie te handhaven was samenwerking noodzakelijk. Daarnaast was de VSE ervan overtuigd dat Europese samenwerking en vrijhandel voorwaarden waren voor wereldvrede. ${ }^{42}$ De leden waren sceptisch ten aanzien van de Volkenbond. Er bestond immers een inherente tegenstelling in de organisatie van de Volkenbond: aan de ene kant moest hij de politieman van de wereld zijn, aan de andere kant had de organisatie geen enkele macht over staten. ${ }^{43}$ Volgens de VSE was het grote probleem van de Volkenbond dat de soeve-

40 IISG, Müller, 16.64, T. Mulder-H.C. Müller, 16 mei 1926. H. Doré, Het vredesstreven in Nederland 18941960: een bundel studies (Nijmegen 1985).

41 IISG, Müller, 16.63, 'Korte uiteenzetting van het beginsel der Vereeniging ter bevordering der oprichting van de Vereenigde Staten van Europa'. IISG, Müller, 16.64, T. Mulder-H.C. Müller, 9 november 1925. 42 'Korte uiteenzetting'.

43 'Letter to the Secretary-General of the League of Nations', Europa!', 1.4 (oktober 1932). reiniteit van de lidstaten gerespecteerd werd. ${ }^{44}$ Een Centrale Europese Regering met zeggenschap over de nationale regeringen was noodzakelijk. Deze regering zou niet almachtig zijn, maar in alle zaken de subsidiariteit respecteren. ${ }^{45}$ Niettemin zou de Europese regering de enige zijn met een leger, terwijl de nationale regeringen alleen de beschikking zouden hebben over een politiemacht.

Voor de VSE waren economische regelingen ondergeschikt aan het politieke doel van een Europese regering. Toch hadden de leden duidelijke economische ideeën die grotendeels aansloten bij de algemene opinie in Nederland. De VSE was tegen quota's en tarieven, die 'een kanker voor ons moderne handelsleven waren' en leidden tot armoede, internationale spanningen en uiteindelijk tot oorlog. In plaats daarvan moest het recht op vrijhandel worden erkend. ${ }^{46}$ Monetair gezien zou de Gouden Standaard de Europese valuta's met elkaar verbinden.

Voor wat betreft de exploitatie van overzeese gebieden onderschreef de VSE de standaard rechtvaardiging voor kolonialisme. De leden vonden dat de Europeanen rechten hadden verworven door mee te werken 'tot de vervulling van de voorwaarden voor de exploitatie van de hulp-

44 'Genève', Europa! 1.1 (juli 1932); J.A. van Sijn, 'Opgang of ondergang. Europeesche aaneensluiting of ontbinding van Europa', Europa! 1.3 (september 1932); 'Letter to the Secretary-General of the League of Nations'; T. Mulder, 'De Vereenigde Staten van Europa', Europa! 1.5 (november 1932); T. Mulder, 'De Vereenigde Staten van Europa', Europa! 1.6 (december 1932).

45 'Korte uiteenzetting'.

46 Ibidem. Zie ook: T. Mulder, 'De plaats van de Vereenigde Staten van Europa in de samenleving', Europa! 1.1 (juli 1932), J.H. Ros, 'De Vereenigde Staten van Europa bezien vanuit christelijk standpunt', Europa! 1.3 (september 1932). 
bronnen buiten Europa en voor een uitgebreid internationaal verkeer. ${ }^{47}$ Omdat niet alle Europese landen in dezelfde mate hadden bijgedragen aan de ontwikkeling van overzeese gebiedsdelen, hadden niet alle Europese staten dezelfde toegang tot de koloniën. De VSE deed een voor een Nederlandse organisatie zeer opmerkelijk voorstel: om een eerlijkere situatie te bewerkstelligen zou de Centrale Europese Regering alle koloniën moeten besturen. Dit zou bijdragen aan een betere situatie in Europa en daarmee aan de wereldvrede: 'De dichte bevolking van Europa [heeft] voor haar bestaan en door haar verlangde welvaart een krachtige exploitatie van de hulpbronnen van andere landen en een onbelemmerd ruilverkeer tusschen ondernemers in die landen en in Europa noodig. ${ }^{48}$

De 'Korte Uiteenzetting' is karakteristiek voor het programma van een grassroots-organisatie. Traditionele Nederlandse uitgangspunten (vrijhandel, Gouden Standaard) die ook bij het ministerie van Buitenlandse Zaken te vinden waren, gingen hand in hand met veel radicaler plannen (Centrale Europese Regering met zeggenschap over Europese koloniën) die karakteristiek waren voor meer grassroots-bewegingen vanuit de samenleving en die het ministerie nooit zou onderschrijven.

\section{Een nieuw begin}

Ondanks de vrij uitgebreide plannen voor de Verenigde Staten van Europa, was de VSE in eerste instantie een vrij kortdurend initiatief. Na de dood van voorzitter Mül-

47 'Korte uiteenzetting'. 48 Ibidem.

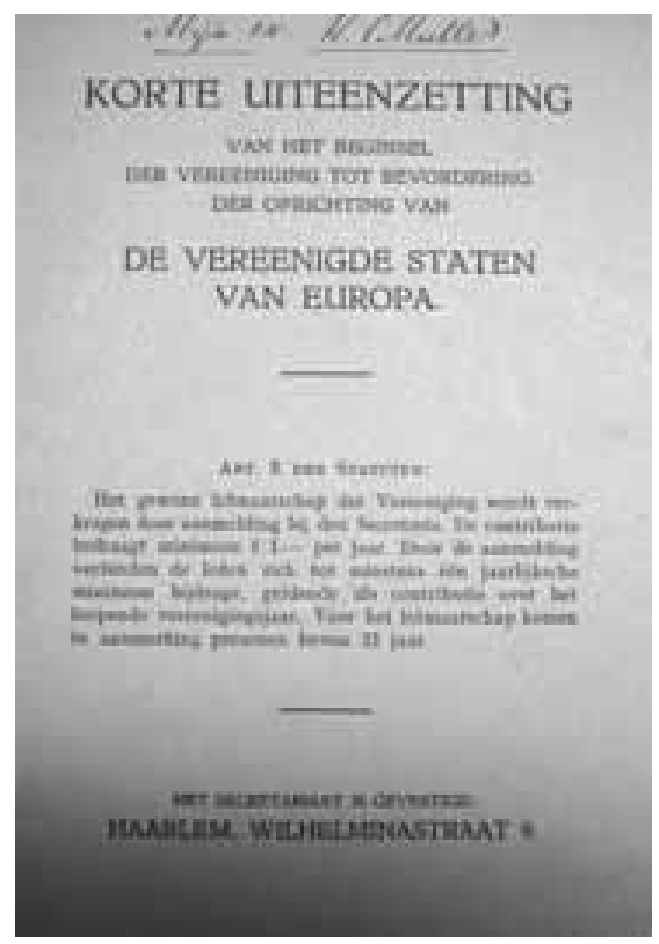

Korte uiteenzetting van het beginsel der Vereeniging tot Bevordering der Oprichting der Vereenigde Staten van Europa (1926)

IISG, Amsterdam, Muller, 16.63

ler in 1927 liet de organisatie sporadisch nog iets van zich horen. ${ }^{49}$ In 1932 werd de vereniging opnieuw opgericht, door grotendeels dezelfde personen. Taco Mulder, de vroegere secretaris, werd de nieuwe voorzitter. Mulder werd door de Franse gezant in Nederland, die voor zijn ministerie geïnteresseerd was in alle Europese initiatieven, omschreven als 'capabel, maar erg pretentieus, ambitieus en ruzie-

49 MAE, Série Y Internationale, 657, Légation française aux Pays Bas, dépêche no. 149, 20 maart 1933. Taco Mulder spreidde enige activiteit ten toon in de jaren 1927-1932. Hij stuurde bijvoorbeeld een ingezonden brief naar de Avondpost op 22 februari 1928. Een ander voorbeeld uit deze periode komt uit De Nieuwe Koers 12.4 (april 1929). 
makend. ${ }^{50}$ A. Funke, de penningmeester en eigenaar van een warenhuis in Haarlem, karakteriseerde hij als een 'zeer eerlijk handelsman, met een onberispelijk karakter en gefortuneerd'. ${ }^{51}$ De belangrijkste nieuwe ontwikkeling was dat de nieuwe vereniging financieel gesteund werd door J.H. Schultz van Haegen, die ook de secretaris van de VSE werd. Het Franse gezantschap was aanmerkelijk minder positief over hem, hij was een man 'van dubieuze moraal en [hij] had een slechte reputatie. ${ }^{52}$ Hoe dit ook zij, de VSE slaagde er in om binnen korte tijd een nationaal netwerk van afdelingen op te zetten. ${ }^{53}$ Tegen het einde van 1932 had de VSE achthonderd leden verspreid over heel Nederland. ${ }^{54}$ De VSE was daarnaast ook internationaal actief. Men werkte samen met het Bloc d'Action Européenne en met de Union Jeune Europe, die afdelingen hadden in Parijs, Genève, Zurich, Berlijn en Breslau (het tegenwoordige Wroclaw) ${ }^{55}$

50 MAE, Série Y Internationale, 657, Légation française aux Pays Bas, dépêche no. 149, 20 maart 1933. 51 Ibidem.

52 Ibidem.

53 Ibidem; IISH, Melchers, 16.83 81, '33-2, C.H. Hagendorn-G.W. Melchers, 25 januari 1933. In maart 1933 waren er afdelingen in Haarlem, Amsterdam, Alkmaar, Leiden, Den Haag, Rotterdam, Amersfoort, Velsen, Dordrecht, Apeldoorn, Utrecht, Arnhem, Nijmegen en Gouda. Europa! 1.9 (maart 1933). Andere bronnen noemen ook afdelingen in Brabant en Limburg. 54 'Jaarverslag van de secretaris', Europa! 1.10 (april 1933).

55 De Nieuwe Koers 15.3 (maart 1932). Voor de BAE en de UJE zie Duchenne, Esquisses d'une Europe nouvelle, 303-530; X. Dehan, 'Jeune Europe: des Etats-Unis d'Europe à l'Europe allemande 1930-1940', in: M. Dumoulin ed., Penser l'Europe à l'aube des années 1930. Quelques contributions belges (Louvain-la-Neuve 1995) 151-203; L. Jilek, L'esprit européen en Suisse de 1860 à 1940 (Genève 1990). 'Vereenigingsnieuws', Europa! 1.3 (september 1932); J.H. Schultz van Haegen, 'Jaarverslag van de secretaris', Europa! 1.10 (april 1933).
De nieuwe organisatie nam de beginselen van de oude organisatie over, maar was een stuk ambitieuzer en had meer leden. Hoewel het ministerie van Buitenlandse Zaken normaal erg sceptisch was ten aanzien van Europese samenwerking en niet geporteerd was van dit soort organisaties, kreeg de VSE Koninklijke Goedkeuring. ${ }^{56}$ Het bestuur van de VSE werd ontvangen door de minister van Buitenlandse Zaken, F. Beelaerts van Blokland, die - volgens het jaarverslag van de VSE - 'zeer sympathiek' tegenover de VSE stond. ${ }^{57}$ Daarnaast deed de VSE actief aan ledenwerving. Men organiseerde een conferentie in Groenendaal in Heemstede. Het doel was nieuws over de organisatie te verspreiden onder een breder publiek en om de banden met de leden aan te halen. Toespraken van Mulder, Schultz van Haegen, J.A. van Sijn, en J.H. Ros werden gepubliceerd in Europa!, het tijdschrift van de VSE, en in De Nieuwe Koers, het tijdschrift van de Nederlandse vredesbeweging dat gedrukt werd door Van Sijn. ${ }^{58}$ De conferentie was een groot succes (inclusief de vegetarische optie tijdens het diner).

56 Helaas is geen verklaring gevonden voor waarom deze Koninklijke Goedkeuring afgegeven werd.

57 J.H. Schultz van Haegen, 'Jaarverslag van de secretaris', Europa!, 1.10 (april 1933). De VSE schreef ook aan buitenlandse regeringen met de vraag om zich in te spannen om de VSE op te richten: MAE, Serie Y Internationale, 657, T. Mulder-Directeur du Cabinet du President de la République, 20 januari 1933; 1 augustus 1932 aan Nederlandse Consuls-Generaal; 4 oktober 1932 aan de Secretaris Generaal van de Volkenbond; november 1932 aan Arthur Henderson; 5 januari 1933 aan Europese staatshoofden; 13 maart 1933 aan Reichspresident Von Hindenburg.

58 Zie Europa! 3.1 (september 1932) en De Nieuwe Koers 15.10 (oktober 1932). Ros had bovendien een overeenkomst met De Standaard (de ARP-krant waarvan Colijn redacteur was) om per maand een artikel over de VSE te publiceren. 


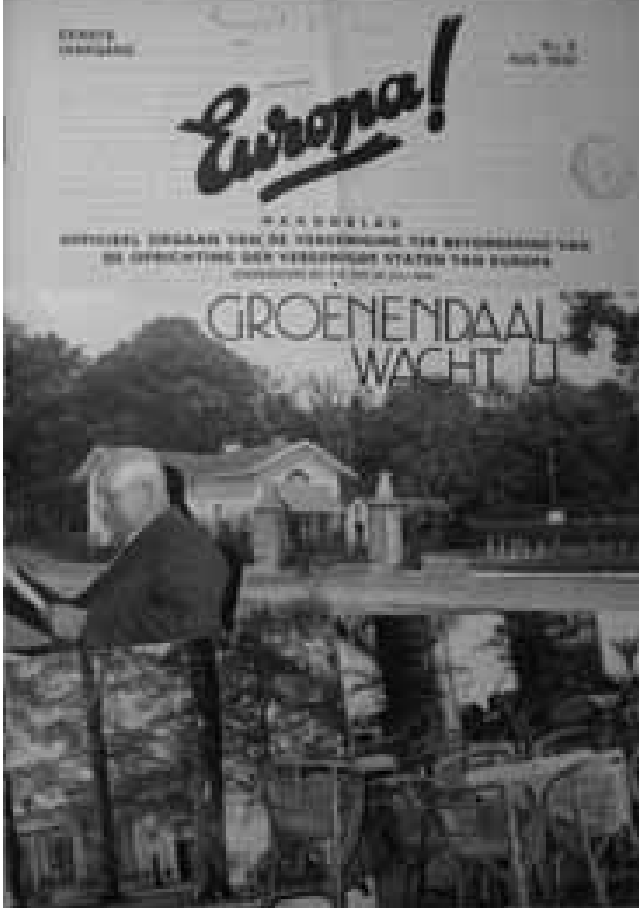

Cover van Europa! met aankondiging VeVcongres in Groenendaal

Europa!, 1.2 (1932)

De VSE gebruikte haar tijdschrift Europa! om nieuws te verspreiden en haar ideeën verder te ontwikkelen. ${ }^{59}$ De meest frequente auteurs waren twee leden van het bestuur, Taco Mulder en J.H. Schultz van Haegen (tevens redacteur), en Van Sijn en Ros. Als de inhoud van Europa! vergeleken wordt met de beginselen uit 1925 blijken de meeste thema's terug te keren. Het idee van een Centrale Europese Regering werd verder ontwikkeld. Deze regering zou lid moeten worden van de Volkenbond. ${ }^{60}$ In een brief aan Arthur Henderson met betrekking tot ontwapening wees de VSE er

59 Het eerste jaar, juli 1932-juni 1933, is gevonden en onderzocht. Aangezien de vereniging zich aansloot bij de Nederlandse Pan-Europa vereniging in de zomer van 1933 is het niet waarschijnlijk dat het tijdschrift daarna doorliep.

6 T. Mulder, 'De Vereenigde Staten van Europa', Europa! 1.4 (oktober 1932). op dat haar idee van een Centrale Europese Regering anders was dan Briands plannen. In plaats van dat de Verenigde Staten van Europa zouden functioneren als onderdeel van de Volkenbond, zou de Volkenbond een stap terug moeten doen als het om Europese vraagstukken ging en zich alleen richten op activiteiten die het Europese niveau overstegen. ${ }^{61}$ Het gaat hier om een vorm van de al eerder vermelde subsidiariteit.

Een aantal onderwerpen uit de 'Korte Uiteenzetting', het programma uit 1925, zoals het idee van convergentie rond de Gouden Standaard, kwam echter nauwelijks terug. De internationale monetaire ontwikkelingen tussen 1926 en 1932 moeten hier debet aan zijn geweest. Andere, dringender zaken, zoals ontwikkelingen in Duitsland, namen de plaats hiervan in en versterkten het animo van de VSE. ${ }^{6}$

In Europa! verscheen een aantal lange artikelen over de relatie tussen de overzeese gebiedsdelen en de Verenigde Staten van Europa. Deze artikelen bouwden voort op de ideeën uit de 'Korte Uiteenzetting'. De VSE erkende de algehele Nederlandse consensus dat Europese samenwerking niet nagestreefd zou moeten worden als dit de relaties met de overzeese gebiedsdelen in gevaar zou brengen. Mulder beargumenteerde echter waarom deze redenering misplaatst was. Men kon overzeese gebiedsdelen niet exclusief voor

61 'Answer to Arthur Henderson, november 1932', Europa! 1.5 (november 1932).

62 Zie bijvoorbeeld:J.H. Ros, 'Mussolini, Duitschland, de Volkenbond en de Vereenigde Staten van Europa', Europa! 1.6 (december 1932); J.H. Ros, 'Welvaart en macht. Ongezond nationalisme en gezond internationalisme', Europa! 1.8 (februari 1933); 'Elleboog-ruimte', Europa! 1.9 (maart 1933); 'Brief aan den Rijkspresident Von Hindenburg', Europa! 1.9 (maart 1933); Ph.C. 'De muzen in het gedrang', Europa! 1.9 (maart 1933); 'Boekenmoord in Duitsland', Europa! 1.11 (mei 1933). 
eigen gewin gebruiken, de belangen van de lokale bevolking en de internationale gemeenschap moesten hierbij in het oog worden gehouden. De Nederlandse Ethische Politiek en het economische opendeurbeleid sloten hierbij aan; er was al meer buitenlands dan Nederlands kapitaal in Indië. Voor de VSE betekende dit dat zeggenschap van een Centrale Europese Regering geen probleem zou zijn. Als dit ertoe zou leiden dat het Nederlandse kapitaal zich niet zou weten te handhaven, zouden er elders meer dan genoeg mogelijkheden bestaan. De relatie met tropische gebieden was weliswaar essentieel voor de Nederlandse welvaart, maar de essentie van deze relatie zou beter gewaarborgd worden met een Centrale Europese Regering, dan zonder. ${ }^{63}$ Hiermee liep de VSE vooruit op de verhouding tussen Nederland en Indonesië in de jaren vijftig.

De Europeanisering van de koloniën was aan de ene kant zeer radicaal voor Nederlandse begrippen, aan de andere kant sloten de plannen naadloos aan bij de karakteristieken van het Nederlands buitenlands beleid. Het gedurfde plan voor een Europese federatie vond men de beste garantie voor de vrede, maar dit plan was gebaseerd op een internationale analyse die aansloot bij het Nederlandse opendeurbeleid in Indië. De belangen van een kleine exportnatie met een groot overzees rijk maar zonder de middelen om zichzelf te verdedigen werden zo in acht genomen. Redenen voor deze onorthodoxe plannen liggen in de niet-elitaire basis van de vereniging. De leden van de VSE hadden minder persoonlijke ervaring met Indië, minder gevestigde belangen

63 T. Mulder, 'Indië en de Vereenigde Staten van Europa', Europa! 1.2 (augustus 1932). om Indië 'Nederlands' te houden en minder banden met Groot-Brittannië dat Europese samenwerking afwees, terwijl ze op hun eigen manier wel het belang van peace, profits and principles onderschreven.

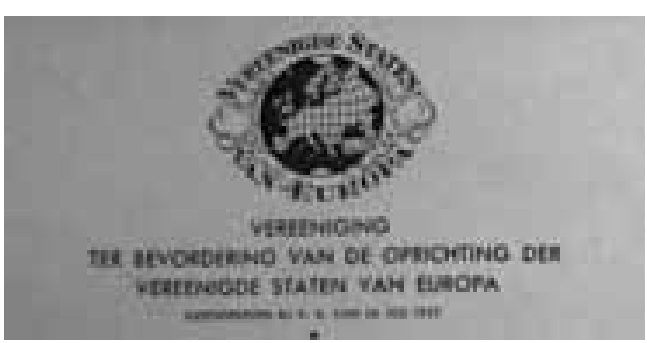

Briefhoofd Vereeniging tot Bevordering der Oprichting der Vereenigde Staten van Europa, 1932

Universiteitsbibliotheek Utrecht, Archief Ritter, Brief Vereeniging tot Bevordering der Oprichting der Vereenigde Staten van Europa - P.H. Ritter, 3 november 1932

\section{De nadagen van de VSE}

Hoewel de VSE erg succesvol was in het creëren van steun voor Europese samenwerking, was de vereniging geen lang leven beschoren. Ruzie tussen de voorzitter, Taco Mulder, en de secretaris, Schultz van Haegen, leidde er toe dat de laatste een eigen organisatie oprichtte, Jong Europa. ${ }^{64}$ Jong Europa was erg actief en bestond tot tenminste 1936 en zette de internationale contacten met de Union Jeune Europe voort. ${ }^{65}$ Jong Europa had ook nauwe banden met de Nederlandse vredesbeweging.

64 IISG, Melchers, 16.8381 33-2, C.H. Hagendorn-G.W. Melchers, 31 januari 1933; Nieuw Europa 1.1 (juli 1933). 65 Rossiiskii Gosudarstvennyi Voennyi Arkhiv (RGVA), Moskou, Paneuropa, 554, I, 44, L.J van der Valk-Paneuropa Union, 18-11-1933. De Union Jeune Europe veranderde in 1933 van naam: Ligue pour les Etats-Unis de l'Europe. 
De reden waarom Jong Europa na 1936 lijkt te verdwijnen is dat het rond die tijd duidelijk werd dat politieke samenwerking in Europa in de nabije toekomst onmogelijk zou zijn. Dit betekende niet dat deze activisten hun idealen opgaven, in plaats daarvan keerden ze terug naar de vredesbeweging.

Geconfronteerd met een tekort aan financiële middelen na het vertrek van Schultz van Haegen, voegde de rest van de organisatie zich bij de Nederlandse Paneuropa vereniging die in 1932-1933 werd opgericht. Dit was niet vanzelfsprekend. Veel artikelen in Europa! hadden juist de verschillen tussen de VSE en Paneuropa benadrukt. Naarmate de tijd verstreek is hier een ontwikkeling in te zien. In december 1932 werden de verschillen duidelijk benoemd, zonder dat er naar overlap werd gezocht: de VSE was ervan overtuigd dat Paneuropa alleen een economische unie wilde, terwijl de VSE zowel een economische en politieke unie beoogde. ${ }^{66}$ Vanaf februari 1933 veranderde de houding, de VSE legde contact met Coudenhove die hen aanraadde lid te worden van Paneuropa Nederland. ${ }^{67}$ De VSE publiceerde artikelen waarin ze liet zien dat de standpunten dichter bij elkaar kwamen te liggen - waarbij ze benadrukte dat het Paneuropa was dat opschoof. Wij wensen een staatkundige organisatie die vanzelf een economische met zich mee-

66 T. Mulder, 'De Vereenigde Staten van Europa', Europa! 1.6 (december 1932).

67 RGVA, Paneuropa, 554, I, 44, H.J. Schultz van Haegen-R.N. Coudenhove-Kalergi, 4 januari 1933; R.N. Coudenhove-Kalergi-H.J. Schultz van Haegen, 7 januari 1933; H.J. Schultz van Haegen-R.N. Coudenhove-Kalergi, 14 januari 1933; T. Mulder-R.N. Coudenhove-Kalergi, 1 februari 1933; T. Mulder-R.N. Coudenhove-Kalergi, 13 maart 1933; R.N. Coudenhove-KalergiT. Mulder, 21 maart 1933 . brengt; PEU wil een economische organisatie en koestert de verwachting dat te eniger tijd daaruit ook de politieke zal voorkomen. ${ }^{68}$ De conclusie was dat beide organisaties hetzelfde einddoel hadden (namelijk vrede) en beide het belang van Europese samenwerking voor de Volkenbond benadrukten. Nadat de leden van de VSE waren geraadpleegd werd besloten dat men zich zou aansluiten bij Paneuropa Nederland en dat voormalig VSE-voorzitter Mulder lid zou worden van het bestuur van die organisatie. ${ }^{69}$

\section{Paneuropa Nederland}

De Paneuropa Union was in 1924 opgericht door Richard Coudenhove-Kalergi. Van alle Europese organisaties was dit waarschijnlijk de grootste organisatie, qua leden en beleidsterreinen. Het begin van Coudenhoves activiteiten was de publicatie van zijn boek, Paneuropa, in 1923, daarna richtte hij een uitgeverij en een tijdschrift onder dezelfde naam op. Door het voeren van een zeer uitgebreide correspondentie groeide de Union al snel en telde zij politici, industriëlen, journalisten en bankiers uit heel Europa onder haar leden. Het doel van de organisatie was de creatie van Paneuropa. Paneuropa en zijn koloniën zou een van de vijf krachtenvelden in de wereld moeten worden, naast

68 'Paneuropa en onze vereeniging', Europa! 1.11 (mei 1933).

69 IISH, G.W. Melchers, 16.8381 33-2, C.H. Hagendorn-G.W. Melchers 25 januari 1933; G.W. MelchersC.H. Hagendorn 27 januari 1933; C.H. Hagendorn-G.W. Melchers 31 januari 1933; Bestuur VSE Gouda-G.W. Melchers 8 februari 1933; G.W. Melchers-Bestuur VSE Gouda 9 februari 1933; 'Onze vereeniging en Pan-Europa', Europa! 1.12 (juni 1933); 'Paneuropa en onze vereniging', Europa! 1.11 (mei 1933). 
Panamerika, de Sovjet-Unie, Oost-Azië (Japan, China, Korea) en het Britse koloniale rijk. Binnen Paneuropa lag de focus op Frans-Duitse samenwerking.

$\mathrm{Al}$ sinds 1927 was er in Nederland sprake van een Nederlandse afdeling van deze vereniging. De aanloop naar de oprichting is illustratief voor de spanning tussen de prominente en de meer grassroots-leden die ook na de oprichting zou blijven bestaan. De Paneuropa Union in Wenen had sinds het midden van de jaren twintig Nederlandse leden. ${ }^{70}$ Geïnspireerd door de oprichting van een Belgische Paneuropavereniging in 1926 circuleerden er sinds 1927 plannen voor het oprichten van ook een Nederlandse afdeling: er was genoeg enthousiasme in Nederland, het ontbrak alleen aan de steun van 'een aantal bekende persoonlijkheden'. ${ }^{71}$ Deze steun bleek een terugkerend probleem, of deze persoonlijkheden konden niet gevonden worden, of ze hadden het te druk, ${ }^{72}$ of ze

70 IISG, Melchers, 79, 1931-2, Paneuropa Union-G.W. Melchers, 27 augustus 1931. In 1931 waren er ongeveer 6o Nederlandse leden van de Paneuropa Union in Wenen.

71 Philips Company Archive, Eindhoven (PCA), 919.2 Paneuropa Correspondentie, C. Verhulst-A.F. Philips, 31 augustus 1927; IISG, Vereeniging voor Volkenbond en Vrede $(\mathrm{VvVeV})$, 4, Vergadering Hoofdbestuur VvVeV, 1 september 1927; RGVA, Paneuropa, 554, I, 44, H. Cochius-R.N. Coudenhove-Kalergi, 1 maart 1927. Voor Paneuropa België zie: Duchenne, Esquisses d'une Europe nouvelle, aldaar 253.

72 De voormalig voorzitter van het Permanent Hof van Justitie, B.C.J. Loder, was geïnteresseerd maar had uiteindelijk niet genoeg tijd toen hij lid werd van het Internationale Committee voor Intellectuele Samenwerking in 1932. IISG, Melchers, 16.82. 80, 1932-2, J. Bierens de Haan-G.W. Melchers, 15 september 1932. trokken zich terug, ${ }^{73}$ of - zoals in het geval van de dominee en politicus J.Th. de Visser - ze overleden zodra ze het voorzitterschap hadden aanvaard. ${ }^{74}$

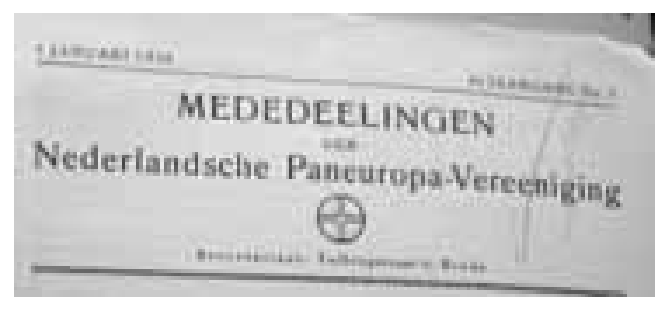

Mededeelingen der Nederlandsche PaneuropaVereeniging

Brabants Historisch Documentatie Centrum, Archief Stulemeijer, 122

Niettemin raakten zowel alledaagse activisten en 'bekende persoonlijkheden' betrokken bij Paneuropa Nederland. Een campagne van het Haagse dagblad $D e$ Avondpost leidde bijvoorbeeld in 1928 binnen een week tot 400 reacties. Hoewel een aantal bekende persoonlijkheden, zoals architect H.P. Berlage, industrieel Anton Philips en bankier Daniel Crena de Iongh, vanaf het midden van de jaren twintig lid was van de Paneuropa Union in Wenen waren het tot het begin van de jaren dertig vooral alledaagse activisten die een $\mathrm{Ne}$ derlandse afdeling probeerden op te zet-

73 De katholieke minister van Kolonien, Ch.J.I.M. Welter, trok zich terug naar aanleiding van Coudenhoves plannen voor een paneuropese partij. RGVA, Paneuropa, 554, I, 44, D. Crena de Iongh-R.N. Coudenhove-Kalergi, 17 januari 1933. Verschillende correspondenten wezen echter ook op zijn voorzitterschap van de onpopulaire Staatscommissie tot verlaging van de rijksuitgaven dat hier een rol in zou hebben gespeeld. IISG, Melchers, 16.82. 80, 1932-2, G.W. Melchers-J. Bierens de Haan, 13 september 1932.

74 De voormalig minister van Onderwijs van de Christelijk Historische Unie J.Th. de Visser (9 februari 1857-14 april 1932) overleed net nadat hij had toegezegd voorzitter te worden van Paneuropa Nederland. RGVA, Paneuropa, 554, I, 44, L.J. van der Valk-R.N. Coudenhove-Kalergi, 12 januari 1933. 
ten. Men kreeg hierbij echter weinig concrete steun uit Wenen en als gevolg hiervan ontwikkelde men een ambivalente relatie met Coudenhove en zijn organisatie.

Aan de ene kant waren de meeste activisten lid van de Paneuropa Union en keek men op tegen Coudenhove. Aan de andere kant verwoordde een van de leden het algemene gevoel dat Coudenhove 'met zijn ondoorgrondelijk half Japansch uiterlijk en zijn onberispelijke smoking' teveel diplomaat was en niet genoeg $\mathrm{fee}$ ling met gewone burgers had. ${ }^{75}$ Dit had niet alleen betrekking op Coudenhoves uiterlijk, men had in het algemeen het gevoel dat hij meer geïnteresseerd was in zijn eigen (financiële) positie dan in het opzetten van een Nederlandse afdeling. ${ }^{76}$ Dit werd versterkt nadat hij in 1930 in Rotterdam en Den Haag twee toespraken had gegeven. Hij had per toespraak 600 gulden gerekend, een aanzienlijk bedrag, en vervolgens gevraagd om met het opzetten van een afdeling te wachten tot hij in april 1931 weer in Nederland zou zijn. ${ }^{77}$ Toen hij pas weer in 1932 in Nederland was, trokken sommigen de conclusie dat hij meer in geld dan Europese samenwerking geïnteresseerd was. ${ }^{78}$

Ondanks deze ambivalente gevoelens zette men de propaganda voor Europese samenwerking voort. De dominee, voormalig SDAP-parlementariër en vrijmetselaar G.W. Melchers is een voorbeeld van

75 IISG, Melchers, 79, 1930, M.D. Dijt-G.W. Melchers, 30 november 1930.

76 IISH, Melchers, 79, 1931-1, W.A. Ruysch-G.W. Melchers, 7 januari 1931.

77 IISH, Melchers, 79, 1931-1, M.D. Dijt-G.W. Melchers, 4 januari 1931.

78 Bijvoorbeeld IISG, Melchers, 79, 1931-1, G.W. Melchers-M.J.F. Ehrbecker, 16 februari 1931. een middenklasse-activist die zich onvermoeibaar inzette voor een Nederlandse afdeling van de Union. ${ }^{79}$ Hoewel hij niet tot de elite behoorde of als een prominent beschreven kan worden, voerde hij een dagelijkse correspondentie met onder andere een aantal 'bekende persoonlijkheden', zoals de havenbaron en drijvende kracht achter de Entente Douanière Européenne, Auguste Plate, die Melchers omschreef als 'een heel prettig man'. ${ }^{80}$ Ook toerde hij door het land om het idee van Europese samenwerking te verspreiden. Hij deed dit onder meer in vrijmetselaarskringen, waar hij ook in het buitenland Europese samenwerking bepleitte.

Activisten waren niet de enigen die twijfels hadden over Coudenhove. Ook de buitenlandse politieke elite was voorzichtig, zij het om iets andere redenen. Zowel het ministerie als prominente activisten waren sceptisch over sommige aspecten van Coudenhoves karakter en manier van doen, waarbij het ministerie zijn plannen voor Europese samenwerking ook niet onderschreef. Zoals hieronder zal blijken waren de 'bekende persoonlijkheden' die Paneuropa steunden echter vrij positief over Coudenhove als persoon, maar twijfelden zij aan de haalbaarheid van zijn plannen en de mogelijkheden

79 Voor Melchers zie: G.W.B. Borrie, 'Gerrit Willem Melchers (1869-1952)', in: Idem., Het leven als een te voltooien bouwwerk. Vijf portretten van vrijmetselaren (Zutphen 2000) 103-140, aldaar 132-136; J.M. Welcker, 'Een "rode" dominee, Gerrit Willem Melchers 18691952', Mededelingenblad orgaan Nederlandse Vereniging tot beoefening van de Sociale Geschiedenis 37 (1970) 2-21; J.M. Welcker, 'Gerrit Willem Melchers', in: Biografisch woordenboek van het socialisme en de arbeidersbeweging in Nederland, deel 3 (Amsterdam 1988) 135-139.

80 GR, Plate, 422, 7, A. Plate-D. Crena de Iongh, 15 december 1931. 
tot de oprichting van een afdeling in $\mathrm{Ne}$ derland.

In de aanloop naar de oprichting van een Nederlandse afdeling bepaalden verschillende publieke figuren hun houding ten aanzien van Coudenhove en zijn programma. De invloedrijke reder en voorzitter van de Amsterdamse Kamer van Koophandel, Ernst Heldring, was in zijn dagboek positief over Coudenhove die hij omschreef als een 'nog jeugdig, zeer intelligent en goed onderlegd man'. Toen Coudenhove Heldring echter vroeg om een Nederlandse afdeling op te zetten, antwoordde Heldring dat hoewel Paneuropa gewenst was, de haalbaarheid twijfelachtig was. In plaats van dat FransDuitse verzoening zou leiden tot Europese samenwerking, voorzag hij eerder politieke oppositie en economische strijd in Europa. Voor de Nederlanders was Britse deelname essentieel. Zij vreesden echter dat Groot-Brittannië zich van Europa af zou keren en zich zou richten op de dominions. Tot die tijd kon Nederland het zich niet veroorloven om de banden met het continent aan te halen. Als "Engeland "om" is' zou Heldring zijn mening kunnen veranderen. ${ }^{82}$ Maar ook dan gold: kon Europese samenwerking 'niet op liberale grondslagen, dan past het ons niet $[. .$. met het oog op onze eigen economie en op onze verhouding tot Indië'. ${ }^{83}$ Heldring, wiens professionele en sociale leven nauw verbonden was met Indië, wees Coudenhove er op dat deze relatie een dominerende rol in de Nederlandse politiek speelde en vroeg hem hoe hij een open-

814 december 1930. E. Heldring (Joh. de Vries ed.), Herinneringen en dagboek van Ernst Heldring (18711954) (Groningen 1970) 902.

826 december 1930. Idem, aldaar 903.

83 Ibidem. deurbeleid in Indië zag in combinatie met Europese samenwerking. Heldring was er beducht voor dat een 'Europa voor de Europeanen' met een 'nog sterker kreet "Azië voor de Aziaten"' beantwoord zou worden. ${ }^{84}$ Ondanks al deze bedenkingen was Heldring geïnspireerd door Coudenhove. Hij werd lid van de Entente Douanière Européenne en wijdde de altijd druk bezochte nieuwjaarstoespraak van de Amsterdamse Kamer van Koophandel in 1931 aan het onderwerp van de Europese samenwerking. In de toespraak erkende hij dat Paneuropa een logische en natuurlijke basis had omdat Europa moest samenwerken om haar ondergang te voorkomen. Niettemin leidden sommige van de ideeën die met Paneuropa verbonden waren tot bedenkingen, vooral in verband met de positie van Nederland als vrijhandelsnatie en koloniale macht met zijn belang bij (economische) banden met Groot-Brittannië. ${ }^{85}$

Banden met de koloniën waren vanuit Nederlands oogpunt cruciaal. De paneuropese ideeën gingen voorbij aan het feit dat de koloniën langzaamaan ophielden objecten van uitbuiting te zijn en meer en meer in het belang van de lokale bevolking werden geregeerd,' aldus Heldring. ${ }^{86}$ Koloniale machten moesten volgens hem daarom hun belangen in de koloniën betrekken bij hun afwegingen ten aanzien van Europese samenwerking. Heldring hintte er vervolgens op dat de argumenten

846 december 1930. Idem, aldaar 902-903. 85 GR, Plate 422, 6, Nieuwjaarstoespraak E. Heldring, Voorzitter van de Amsterdamse Kamer van Koophandel, 1931. Cf. F. Trentmann, Free Trade Nation. Commerce, consumption, and civil society in modern Britain (Oxford 2008); Bos, 'De depressie der jaren dertig'. 86 GR, Plate 422, 6, Nieuwjaarstoespraak E. Heldring, Voorzitter van de Amsterdamse Kamer van Koophandel, 1931. 
die voor Groot-Brittannië golden - dat de structuur van het koloniale rijk en met name de constitutionele verhoudingen met de dominions die al een Gemenebest vormden, deelname aan een Europees Gemenebest verhinderden - ook zouden gelden voor andere landen wiens koloniën op weg naar zelfbeschikking waren, zoals Nederland. Onafhankelijk van hoe ver ze op weg waren, de koloniën waren niet langer objecten die zomaar onder Europees gezag gebracht konden worden zonder dat de belangen van deze gebieden in ogenschouw waren genomen. Deze redenering voerde Heldring aan om geen lid te worden van Paneuropa Nederland.

Auguste Plates mening was vergelijkbaar met die van Heldring, maar hij werd wél lid van Paneuropa Nederland. De interesse van Plate in Europese samenwerking ging terug tot 1926-1927 toen hij in aanraking kwam met de Europäische Zollunion en de Franse zustervereniging, de Union Douanière Européenne. Hij richtte een Nederlands comité op, de Entente Douanière Européenne. Plate zag Europese samenwerking als economisch onafwendbaar. ${ }^{87}$ Als voorzitter van de Nederlandsche Vereeniging voor Vrijhandel was hij geïnteresseerd in elk initiatief dat handelsbelemmeringen kon verminderen. Gezien de aarzelende houding van het ministerie ten aanzien van Paneuropa merkte hij op dat het ontwikkelen van een sensibiliteit voor Europese samenwerking nuttig kon zijn. Wat vandaag onmogelijk was, kon morgen mogelijk worden. ${ }^{88}$ Hiermee gaf hij expliciet aan dat Europese samenwerking een proces van de lange termijn was, waar echter wel al

87 GR, Plate, 422, 37, A. Plate-M.P.L. Steenberghe, 25 maart 1932.

88 GR, Plate 9o, A. Plate-E. van Raalte, 6 juni 1929. meteen aan gewerkt moest worden. Hoewel Plate waardering had voor Coudenhove en zijn activiteiten, vond hij hem 'niet iemand dien men in Holland gemakkelijk zal kunnen volgen. Onze vraagstukken zijn nu eenmaal anders dan die in Centraal- en Oost-Europa. ${ }^{89}$ Daarnaast benadrukte ook Plate het belang van Indië, waar hij als jong architect bijvoorbeeld het treinstation van Semarang had ontworpen. Net als Heldring had Plate twijfels bij de haalbaarheid van Coudenhoves plannen, die hij omschreef als 'simplistisch'. ${ }^{90}$ Plates interesse in Europa was daarom een meer algemene bezorgdheid over Europese samenwerking, dan een interesse in de Paneuropa Union. Zijn lidmaatschap van Paneuropa Nederland kwam dan ook voort uit de inschatting dat de Nederlandse afdeling Coudenhove niet in alles zou hoeven volgen. ${ }^{91}$ Daarnaast was zijn lidmaatschap ook een manier om een oogje in het zeil te houden en te voorkomen dat té wilde plannen voorgesteld zouden worden.

De meningen van deze publieke figuren laten zien dat onvoorwaardelijk enthousiasme voor Paneuropa beperkt was onder Nederlandse prominenten als gevolg van twijfels over de haalbaarheid van de samenwerking en over de Nederlandse positie ten aanzien van Groot-Brittannië en Indië. Hun interesse in het stimuleren van de handel tijdens de economische depressie van de jaren dertig bracht sommigen ertoe om in 1932 Paneuropa Nederland op te richten. De voorzitter van de Nederlandse afdeling werd

89 GR, Plate, 422, 6, A. Plate-D. Crena de Iongh, 9 juni 1931.

90 GR, Plate, 422, 31, A. Plate-D. Crena de Iongh, 30 maart 1932.

91 GR, Plate, 422, 6, A. Plate-D. Crena de Iongh, 9 juni 1931. 
J. van Stolk, directeur van de Lijm- en Gelatinefabriek in Delft. Zelfs de zeer sceptische Franse gezant moest toegeven dat zeer bekende namen lid waren geworden: in het bestuur en het comité van aanbeveling zaten politici, industriëlen, bankiers en professoren. ${ }^{92}$ Naast Plate, Philips en de erg actieve Crena de Iongh, zaten bijvoorbeeld ook voormalig en toekomstig minister-president Colijn, de president van De Nederlandsche Bank L.J.A. Trip, de invloedrijke industrieel en voorzitter van de Internationale Kamer van Koophandel Frits Fentener van Vlissingen van de Steenkolen Handelsvereeniging, reder D.G. van Beuningen en Willem Drees, destijds wethouder in Den Haag en later minister-president. Invloedrijke namen waren cruciaal bij het oprichten van een geloofwaardige organisatie en sommigen van deze bekende namen zoals Crena of de reder D.A. Delprat waren zeer actief betrokken. Niettemin waren mensen zoals de eerder genoemde Melchers, die lid werd van het comité van aanbeveling naast de 'bekende persoonlijkheden', of L.J. van der Valk, de advocaat die secretaris van Paneuropa Nederland werd, essentieel voor het functioneren van de organisatie. Ze organiseerden bijeenkomsten, gaven toespraken, en zetten een effectieve organisatie op. Deze activiteiten resulteerden in januari 1934 in ongeveer vijfhonderd leden uit zowel de elite als de middenklasse. ${ }^{93}$ De voormalige leden van de VSE droegen in belangrijke mate bij aan dit ledental en gaven de vereniging een meer middenklassekarakter. Ter vergelij-

92 PCA, 919.2 PanEuropa Correspondentie, L.J. van der Valk-A.F. Philips, 21 maart 1932, MAE, SDN, UE, 2495, Ministre de France au Pays-Bas-Ministre des Affaires Etrangères, 21 maart 1933.

93 Stedelijk Archief Amsterdam (SA), Delprat, J. van Stolk-D. Crena de Iongh, 22 januari 1934. king: de Belgische afdeling van Paneuropa had nooit meer dan tweehonderd leden. ${ }^{94}$

Hoewel de Nederlandse afdeling ook deelnam aan de internationale activiteiten van de Paneuropa Union, zoals de Paneuropese Economisch Conferentie in Wenen in $1934^{95}$, leidden vragen over de haalbaarheid van Coudenhoves plannen ertoe dat Paneuropa Nederland een redelijk onafhankelijke koers voer. De Nederlandse (en ook de Belgische) afdeling was bijvoorbeeld een stuk positiever over de Volkenbond dan Coudenhove. Een andere bijzonderheid was de aandacht voor regionale samenwerking, zoals met de Scandinavische staten en tussen Nederland en België. ${ }^{96}$ Zoals de voorgaande analyse liet zien, was deze specifieke interesse het gevolg van een nadruk op de exportmogelijkheden. De Nederlandse welvaart was afhankelijk van handel en daarom spoorde Paneuropa Nederland iedereen aan om een organisatie te steunen 'welke de internationale samenwerking wil bevorderen en welke ten doel heeft de vorming van een groote economische eenheid waardoor voor de producten van de Nederlandsche industrie en van den $\mathrm{Ne}$ derlandschen land- en tuinbouw een uit-

94 Duchenne, Esquisses d'une Europe nouvelle, 277. 95 Mededeelingen der Nederlandsche Paneuropa Vereeniging, 4.1 (januari 1936). Gemeentearchief Rotterdam (GR), Familie Mees, PEU 39, 2188, Toespraak W.C. Mees, 'Paneuropäische Wirtschaftskonferenz, Neue Bahnen zur Bekämpfung wirtschaftlicher Depressionen'.

96 Archief De Nederlandsche Bank Amsterdam (DNB), Trip, 17441; Brabants Historische Informatie Centrum (BHIC), Stulemeijer 108, Paneuropa Nederland mei 1933; GR, Plate, 422, 43, L.J. van der Valk-A. Plate, 14 maart 1933; G.W. Melchers, Pan-Europa internationale solidariteit in ethisch en economisch opzicht (Den Haag 1930); G. van Roon, Small states in years of depression. The Oslo alliance 1930-1940 (Assen 1989). 
gestrekt afzetgebied zal zijn verzekerd. ${ }^{97}$ Ontwikkelingen in Ottawa, waar in 1932 de British Empire Economic Conference plaatsvond - die leidde tot Brits protectionisme - werden als waarschuwing voor Europa opgehouden. ${ }^{98}$

Aan Coudenhoves plannen om de ontwikkeling en de exploitatie van de Europese koloniën gezamenlijk te organiseren werd weinig aandacht besteed. Ten eerste lag de nadruk van Coudenhoves plannen op Afrika en niet op Azië, waardoor de relevantie voor Nederland afnam. Daarnaast vond men het geven van een voorkeursbehandeling voor Europeanen niet haalbaar. Door het opendeurbeleid in $\mathrm{Ne}-$ derlands-Indië hadden Europeanen al toegang. Een exclusief Europees project zou de Verenigde Staten, Groot-Brittannië en Japan uitsluiten, de drie machten waar Nederland in Zuidoost-Azië zowel op steunde als die men vreesde. ${ }^{99}$ Plannen van voormalig VSE-vertegenwoordigers zoals Taco Mulder om de koloniën onder een Centrale Europese Regering te plaatsen lijken succesvol geneutraliseerd te zijn omdat ze niet meer genoemd werden.

De activiteiten van Paneuropa Nederland namen vanaf 1935 af. Tegen die tijd had een aantal van de bekende persoonlijkheden zoals Plate en Van Beuningen het lidmaatschap opgezegd. ${ }^{100}$ Voorzitter Th. Ligthart (voormalig directeur van de Javaasche Bank in Batavia), die Van Stolk in 1934 was opgevolgd, merkte op dat hij zich ervan van bewust was dat het initiatief van hem moest komen, maar dat de

97 PCA, 919.2 Paneuropa Correspondentie, Rondzendbrief Paneuropa Nederland mei 1933. 98 Ibidem.

99 BHIC, Stulemeijer 108, L.J. van der Valk-J. van Stolk, 22 maart 1932.

100 RGVA, Paneuropa, 544, 1, 44, D.G. van BeuningenR.N. Coudenhove-Kalergi, 25 september 1933. algemene situatie niet erg uitnodigend was. Niettemin had de zaak van internationale samenwerking steun nodig en moest er zoveel mogelijk aandacht voor gevraagd worden - wellicht zonder het woord 'Paneuropa' te noemen. In een opmerkelijke alinea, gezien zijn voorzitterschap van Paneuropa Nederland, legde hij uit dat een woord dat zo tegengesteld was aan nationale belangen twijfel zou kunnen zaaien over de vaderlandsliefde van de leden. ${ }^{101}$ Gebeurtenissen in Duitsland speelden een belangrijke rol in de afname van activiteiten. In januari 1934 antwoordde Drees aan Coudenhove dat 'als sociaal-democraat hij onder de huidige omstandigheden niet naar Wenen kon reizen om de Paneuropese conferentie bij te wonen'. ${ }^{102}$ De situatie in Duitsland en Oostenrijk beperkte de mogelijkheden voor een partijloze organisatie ten behoeve van Europese samenwerking. In juni 1934 nodigde de secretaris Van der Valk de leden van het Comité van Aanbeveling uit om te overleggen over wat de taken van de vereniging zouden moeten zijn in de huidige situatie. ${ }^{103}$ President van De Nederlandsche Bank Trip, die al een maand eerder had laten weten dat hij 'onder de huidige omstandigheden weinig opgewektheid gevoel[de] om met eenig enthousiasme over Europeesche samenwerking te spreken', ${ }^{104}$ antwoordde dat

101 Toespraak Th. Ligthart voor de Haagse afdeling van de Vereeniging voor Volkenbond en Vrede, 8 februari 1935, IISG, VvVeV, 47, Afdeeling Den Haag, Jaarverslag 1935 .

102 Nationaal Archief Den Haag (NA), 2.21.286, W. Drees 1192, W. Drees-R.N. Coudenhove-Kalergi, 20 januari 1934.

103 DNB, Trip, 17441, L.J. van der Valk-Raad van Toezicht, 13 juni 1934 .

104 DNB, Trip, 17441, L.J.A. Trip-L.J. van der Valk, 5 mei 1933. 
het lastig was een specifieke taak te benoemen.

Het zou, naar het mij voorkomt, inderdaad geen zin hebben en uit een praktisch oogpunt volkomen nutteloos zijn, om, zonder eenige blijken van genegenheid der groote Europeesche mogendheden om in de gewenschte richting werkzaam te zijn, van uit een klein land als Nederland eenige resultaat van een actie verwachten. ${ }^{105}$

Trips enige advies was 'afwachten!'106 Ondanks deze raadgeving zette hij zijn correspondentie met Coudenhove wel voort. ${ }^{107}$

\section{Conclusie}

Steun voor Europese integratie in Nederland ontstond niet uit het niets gedurende of na de Tweede Wereldoorlog. Om de geschiedenis van de Europese samenwerking te begrijpen moeten we de periode voor de Tweede Wereldoorlog, niet-statelijk actoren en buiten-Europese ontwikkelingen en overwegingen in onze analyse betrekken. Door deze factoren te benadrukken sluit dit artikel aan bij de $\mathrm{New}$ Political History. De Eerste Wereldoorlog zorgde voor een doorbraak in Europabrede discussies over Europese samen-

105 DNB, Trip, 17441, L.J.A. Trip-L.J. van der Valk, 20 juni 1933 .

106 DNB, Trip, 17441, L.J.A. Trip-L.J. van der Valk, 20 juni 1933 .

107 DNB, Trip, 17441, R.N. Coudenhove-Kalergi-L.J.A. Trip 26 april 1934; L.J.A Trip-R.N. Coudenhove-Kalergi, 2 mei 1934; R.N. Coudenhove-Kalergi-L.J.A. Trip, 4 juni 1934; L.J.A Trip-R.N. Coudenhove-Kalergi, 15 juni 1934; R.N. Coudenhove-Kalergi-L.J.A Trip, 16 juli 1934; R.N. Coudenhove-Kalergi-L.J.A. Trip, 11 oktober 1934. werking. De situatie binnen Europa en ontwikkelingen daarbuiten brachten veel Europeanen ertoe de mogelijkheden voor Europese samenwerking te gaan onderzoeken en projecten op te zetten. Ook in Nederland was dit het geval. Dat het animo in Nederland minder groot was dan elders in Europa, had zowel binnen- als buiten-Europese redenen. Doordat de neutraliteit tijdens de Eerste Wereldoorlog behouden was gebleven, voelde men in Nederland minder druk om alternatieve manieren te zoeken om vrede en welvaart te bewaren dan in andere Europese landen. Daarnaast leken de belangen van de koloniale vrijhandelsnatie tegengesteld aan Europese blokvorming en meer gebaat bij mondiale initiatieven. Dit leidde tot een zekere terughoudendheid ten aanzien van Europese samenwerking in Nederland.

Door zowel statelijke als niet-statelijke actoren te onderzoeken heeft dit artikel laten zien dat deze terughoudendheid niet verhinderde dat er een Europese beweging ontstond in Nederland. Deze beweging bestond uit organisaties met zowel prominente als alledaagse leden, waarvan Paneuropa Nederland en de VSE voorbeelden zijn. De meer grassroots-organisaties deden voor Nederlandse doen zeer radicale voorstellen, maar ook zij onderschreven grotendeels het belang van peace, profits and principles.

Deze belangen stonden voor de prominenten meer op de voorgrond. De belangen van Nederland overzee, vrijhandel en goede relaties met Groot-Brittannië maakten dat zij zich pas later en in mindere mate dan in andere landen voor $\mathrm{Eu}-$ ropese samenwerking ging interesseren. Toen de economisch depressie bleef 
voortduren en een grote impact had op de economie in het algemeen en de landbouw in het bijzonder, de wereldwijde economische initiatieven van de Volkenbond niet leken te werken en ook GrootBrittannië de Gouden Standaard en vrijhandel vaarwel zegde, steunden zogenaamde 'invloedrijke persoonlijkheden' Europese plannen. Europese samenwerking werd zo een tweede keus toen mondiale oplossingen niet mogelijk bleken.

Ondanks de verschillen tussen verschillende typen activisten nuanceert dit artikel het onderscheid tussen 'elite' en 'gewone burgers' dat in de literatuur over permissive consensus-constraining dissensus zo op de voorgrond treedt. Door het inzicht van Europese samenwerking als tweede keus wordt ook de standaard periodisering genuanceerd. Hoewel tijdens het interbellum in Nederland geen grote beslissingen op het terrein van Europese samenwerking zijn genomen, zorgden de activiteiten van de Europese beweging in Nederland er wel voor dat Europese samenwerking op de agenda kwam, van zowel alledaagse grassroots-activisten als prominente beleids- en opiniemakers. Hierdoor werd draagvlak gecreëerd waarop na de Tweede Wereldoorlog een permissive consensus gebouwd zou worden. De mondiale belangen van Nederland werden echter ook toen niet uit het oog verloren.

\section{Over de auteur}

Anne-Isabelle Richard is Universitair Docent aan de Universiteit Leiden. $\mathrm{Zij}$ is aan de Universiteit van Cambridge gepromoveerd op een proefschrift over de invloed van het kolonialisme op de Europese bewegingen in Frankrijk en Nederland in het interbellum. Haar nieuwe NWO Veni-project betreft Afrikaanse perspectieven op het idee van Eurafrika, 1918-1980.

E-mail: a.i.richard@hum.leidenuniv.nl 
